\title{
KINERJA KEUANGAN DENGAN PENDEKATAN Z-SCORE ALTMAN DAN X-SCORE ZMIJEWSKI DALAM MEMPREDIKSI KEBANGKRUTAN PADA PERUSAHAAN MANUFAKTUR YANG TERDAPAT DI BURSA EFEK INDONESIA PERIODE 2016-2018
}

\author{
Ahmad Sumarlan ${ }^{1}$, Eti Arini ${ }^{2}$, Agustin Ita Pratiwi ${ }^{3}$ \\ ${ }^{1,2,3}$ Fakultas Ekonomi dan Bisnis, Universitas Muhammadiyah Bengkulu \\ Email: Ahmadsumarlan@ umb.ac.id, etiarini@ umb.ac.id
}

\begin{abstract}
ABSTRAK
Setiap perusahaan memiliki keinginan untuk mampu bertahan dalam dunia bisnis dengan tujuan mampu menghasilkan keuntungan secara terus-menerus. Namun tidak terlepas dari harapan tersebut, beberapa perusahaan besar pada akhirnya harus berhenti menjalankan kegiatan usahanya dikarenakan terlilit hutang, gagal dalam perencanaan manajemen yang berdampak pada laporan keuangan yang tidak sehat, yang pada akhirnya dapat menyebabkan kebangkrutan. Penelitian ini bertujuan untuk mengetahui prediksi kebangkrutan perusahaan dan melihat bagaimana tingkat kebangkrutan perusahaan dengan menggunakan pendekatan Z-score Altman dan Z-score Zmijewski pada perusahan manufaktur yang terdaftar di Bursa Efek Indonesia tahun 2016-2018. Jenis penelitian ini adalah penelitian deskriptif kuantitatif. Sampel yang diambil sebanyak 46 perusahaan dengan menggunakan teknik purposive sampling. Hasil penelitian ini menunjukkan bahwa dengan pendekatan Z-score Altman, pada tahun 2016 terdapat 24 perusahaan dalam zona aman, 9 perusahaan dalam zona abu-abu dan 13 perusahaan dalam zona berbahaya. Pada tahun 2017 terdapat 21 perusahaan dalam zona aman, 9 perusahaan dalam zona abu-abu dan 16 perusahaan dalam zona berbahaya sedangkan pada tahun 2018 terdapat 20 perusahaan dalam zona aman, 10 perusahaan dalam zona abu-abu dan 16 perusahaan dalam zona berbahaya. Pada pendekatan X-score Zmijewski, pada tahun 2016 dan 2017 diperoleh hasil 5 perusahaan dalam zona aman dan 41 perusahaan dalam zona berbahaya. Sedangkan pada 2018 diketahui terdapat 4 perusahaan dalam zona aman dan 42 perusahaan lainnya dinyatakan dalam zona berbahaya. Berdasarkan hasil tersebut, dapat disimpulkan bahwa pendekatan X-score Zmijewski lebih banyak mendeteksi tingkat kebangkrutan perusahaan dibandingkan dengan pendekatan Z-score Altman.
\end{abstract}

Kata Kunci: Z-score Altman, X-score Zmijewski, prediksi kebangkrutan.

\begin{abstract}
Every company has a desire to be able to survive in the business world with the aim of being able to generate profits continuously. But not apart from these expectations, several large companies eventually had to stop running their business activities due to debt, failing in management planning which resulted in unhealthy financial reports, which in turn could lead to bankruptcy. This study aims to determine the prediction of company bankruptcy and see how the level of company bankruptcy using the Altman Z-score and Zmijewski's Z-score approaches in manufacturing companies listed on the Indonesia Stock Exchange in 2016-2018. This type of research is a
\end{abstract}


quantitative descriptive study. The samples taken were 46 companies using purposive sampling technique. The results of this study indicate that with the Altman Z-score approach, in 2016 there were 24 companies in the safe zone, 9 companies in the gray zone and 13 companies in the danger zone. In 2017 there were 21 companies in the safe zone, 9 companies in the gray zone and 16 companies in the danger zone, while in 2018 there were 20 companies in the safe zone, 10 companies in the gray zone and 16 companies in the dangerous zone. In Zmijewski's X-score approach, in 2016 and 2017 the results were 5 companies in the safe zone and 41 companies in the dangerous zone. Meanwhile, in 2018 it was found that there were 4 companies in the safe zone and 42 other companies were declared in the dangerous zone. Based on these results, it can be concluded that the Zmijewski X-score approach detects more corporate bankruptcy than the Altman Z-score approach.

\section{Keywords: Altman's Z-score, Zmijewski's X-score, bankruptcy prediction.}

\section{PENDAHULUAN}

Kebangkrutan diartikan sebagai kegagalan perusahaan dalam menjalankan oprasi untuk mencapai tujuan yang merupakan akumulasi dari kesalahan pengelolaan perusahaan dalam jangka panjang. Karena itu, diperlukan alat untuk mendeteksi potensi kebangkrutan yang mungkin dialami perusahaan. Perusahaan harus sedini mungkin melakukan berbagai analisis terutama analisis yang menyangkut kebangkrutan perusahaan. Dengan melakukan analisis maka sangat bermanfaat bagi perusahaan untuk melakukan antisipasi yang dapat menghindari atau mengurangi resiko kebangkrutan tersebut. Prediksi potensi kebangkrutan dilakukan untuk memperoleh peringatan awal kebangkrutan (tanda-tanda bangkrut). Semakin awal tanda-tanda kebangkrutan tersebut diketahui, semakin baik bagi pihak manajemen karena pihak manajemen bisa melakukan perbaikan agar kebangkrutan tersebut tidak terjadi dan perusahaan dapat mengantisipasi atau membuat strategi untuk menghadapi jika kebangkrutan benar-benar menimpa perusahaan.

Dalam Metode Z-Score model Altman dilakukan analisis kebangkrutan yang dapat membantu perusahaan untuk mengantisipasi kemungkinan perusahaan dalam mengalami kebangkrutan yang disebabkan oleh masalah-masalah keuangan dengan memperhitungkan dan menggabungkan rasio-rasio keungan tertentu dalam prusahaan dalam suatu persamaan deskriminan yang akan menghasilkan skor tertentu yang akan. Sedangkan pendekatan X-Score Zmijewski menganalisis rasio menggunakan rasio keuangan yang mengukur kinerja, leverage dan likuiditas suatu perusahaan untuk model prediksinya. Model ini menekankan pada jumlah uang sebagai komponen yang paling berpengaruh terhadap kebangkrutan. Di Indonesia, terdapat beberapa perusahaan besar mengalami kasus kebangkrutan, dimulai dari kasus yang terjadi pada |maskapai Mandala Airlines yang kemudian berganti nama menjadi Tiger air Mandala pada 2011 mengumumkan tengah terlilit utang dan pendapatan yang tidak mampu menutupi biaya operasional sehingga berakhir menghentikan seluruh operasionalnya. Tidak hanya itu, pada sub sektor manufaktur, perusahaan PT. Tiga Pilar Sejahtera Food Tbk melalui salah satu anak usahanya yaitu PT. Indo Beras Unggul menyatakan bangkrut dikarenakan kasus pengoplosan beras yang menyebabkan perusahaan mulai mengalami masalah keuangan yang dimulai dengan keterlambatan pembayaran bunga yang berakhir pada gagal bayar, ditambah dengan skandal laporan keuangan yang dilakukan oleh direktur utama perusahaan dalam penggelembungan dana lebih dari 4 triliun rupiah. 
Pada dasarnya perusahaan-perusahaan yang mengalami kebangkrutan tersebut disebabkan oleh: 1). Masalah keuangan, dimana kondisi utang lebih besar dibandingkan dengan pendapatan sehingga menyebabkan likuiditasnya menjadi kurang baik.2). Pengalihan usaha secara besarbesaran. Perusahaan gagal melihat pangsa pasar sehingga produk yang dihasilkan tidak sesuai dengan tren dan kebutuhan konsumen. 3)Berkurang atau bahkan hilangnya tingkat kepercayaan masyarakat terhadap perusahaan, sehingga menyebabkan perusahaan mengalami penurunan jumlah pendapatan. 4). Penggelapan dana yang dilakukan oleh pihak manajemen juga dapat menjadi penyebab perusahaan mengalami penurunan nilai pendapatan yang dapat menyebabkan kebangkrutan. 5). Kelalaian yang dilakukan oleh pihak manajemen dalam mengawasi setiap kegiatan atau aktivitas yang dilakukan oleh para pegawai, kurangnya keterampilan sumber daya manusia.

Berdasarkan penelitian terdahulu, dilakukan oleh Pricilia Claudia Pangkey tentang "Analisis Prediksi Kebangkrutan Dengan Menggunakan Metode Altman dan Metode Zmijewski Pada Perusahaan Bangkrut Yang Pernah Go Public di Bursa Efek Indonesia" dimana hasilnya menunjukkan jika metode Altman dianggap lebih akurat dibandingkan metode Zmijewski. Nindya Damayanti tentang "Analisis Perbandingan Model Prediksi Kebangkrutan Altaman Z-score dan Zmijewski X-score di BEI Periode 2011-2015" yang menganggap metode Altman lebih akurat memprediksi kebangkrutan diwaktu satu dan dua tahun sebelum masa kebangkrutan. Cicha Lestari, tentang "Prediksi Kebangkrutan Berdasarkan Metode Altman Z-score Pada Perusahaan Makanan Dan Minuman Yang Terdaftar Di BEI Periode 2011-2016" menemukan satu perusahaan yang diprediksi mengalami kebangkrutan. Sehingga, tujuan penelitian ini adalah untuk mengetahui tingkat kebangkrutan perusahaan manufaktur yang terdaftar di Bursa Efek Indonesia periode 20162018 menurut metode Z-Score Altman dan X-Score Zmijewski serta perusahaan manakah yang mendekati dari prediksi kebangkrutan tersebut.

\section{TINJAUAN LITERATUR \\ Kinerja Keuangan}

Kinerja keuangan adalah suatu analisis yang dilakukan untuk melihat sejauh mana suatu perusahaan telah melaksanakan dengan menggunakan aturan-aturan pelaksanaan keuangan secara baik dan benar. Hal ini sangat penting agar sumber daya digunakan secara optimal dalam menghadapi perubahan lingkungan (Fahmi 2011:2).

Menurut Munawir (2012:31) menyatakan bahwa tujuan dari pengukuran kinerja keuangan perusahaan adalah:

1. Mengetahui tingkat likuiditas. Kemampuan suatu perusahaan untuk memenuhi kewajiban keuangan yang harus segera diselesaikan pada saat ditagih.

2. Mengetahui tingkat solvabilitas. Kemampuan perusahaan untuk memenuhi kewajiban keuangannya apabila perusahaan tersebut dilikuidasi baik keuangan jangka pendek maupun jangka panjang.

3. Mengetahui tingkat rentabilitas. Rentabilitas atau yang sering disebut profitabilitas menunjukkan kemampuan perusahaan untuk menghasilkan laba selama periode tertentu.

4. Mengetahui tingkat stabilitas. Stabilitas menunjukkan kemampuan perusahaan untuk melakukan usahanya dengan stabil, yang diukur dengan mempertimbangkan kemampuan 
perusahaan untuk membayar utang-utangnya serta membayar beban bunga atas utangutangnya tepat pada waktunya.

\section{Kebangkrutan}

Kebangkrutan diartikan sebagai kegagalan perusahaan dalam menjalankan operasi untuk mencapai tujuannya. Kebangkrutan terjadi apabila semua utang perusahaan melebihi nilai wajar aset totalnya, dengan kata lain perusahaan bernilai negatif atau berada dalam keadaan actual insolvency.(Rudianto:2013:251).

Sedangkan menurut Brigham (2012:2-3) kebangkrutan sebagai suatu kegagalan yang terjadi pada sebuah perusahaan dapat diartikan sebagai berikut:

1 Kegagalan Ekonomi (Ekonomic Distressed). Yaitu kondisi dimana perusahaan kehilangan uang atau pendapatan perusahaan tidak mampu menutupi biayanya sendiri.

2 Kegagalan Keuangan (Financial Distressed). Kondisi perusahaan dimana kesulitan dana baik dalam arti dana dalam pengertian kas atau dalam pengertian modal kerja.

\section{Metode Z-Score Altman}

Analisis Z-Score adalah metode untuk memprediksi keberlangsungan hidup suatu perusahaan mengkombinasikan beberapa rasio keuangan yang umumnya dan pemberian bobot yang berbeda satu dengan yang lainnya. Menurut Edward I Atman dalam buku Rudianto (2013:254) Analisis ZScore adalah metode untuk memprediksi kebangkrutan hidup suatu perusahaan dengan mengkombinasikan beberapa rasio keuangan yang umum dan pemberian bobot yang berbeda satu dengan lainnya.

1. Metode Z-Score Altman Pertama

Analisis Altman Z-score pertama kali dikemukakan oleh Edward I Altman. Setelah menyeleksi 22 rasio keuangan, ditemukan 5 rasio yang dapat dikombinasikan untuk melihat perusahaan yang bangkrut dan tidak bangkrut. Perkembangan rumusan yang dikembangkan oleh Altman dihasilkan dari penelitian atas berbagai perusahaan manufaktur di Amerika Serikat yang menjual sahamnya di bursa efek. Karena itu, rumus tersebut lebih cocok digunakan untuk memprediksi keberlangsungan usaha perusahaan- perusahaan manufaktur yang go public.

Altman menyatakan bahwa jika perusahaan memiliki indeks kebangkrutan 2,99 atau di atasnya, maka perusahaan tidak termasuk yang dikategorikan akan mengalami kebangkrutan. Sedangkan perusahaan yang memiliki indeks kebangkrutan 1,81 atau dibawahnya, perusahaan tersebut termasuk kategori bangkrut. Skor tersebut harus dibandingkan dengan standar penilaian berikut ini untuk menilai keberlangsungan hidup perusahaan:
a. Jika nilai $Z>2,99$
= Zona Aman.
b. Jika nilai $1,81<Z<2,99$
= Zona Abu-abu
c. Jika nilai $Z<1,81$
= Zona Berbahaya

2. Metode Z-Score Altman kedua (Revisi)

Rumus dari hasil penelitian tersebut lebih tepat digunakan untuk perusahaan manufaktur yang tidak menjual sahamnya di bursa efek, menyatakan rumus Z-Score tersebut lebih tepat digunakan untuk perusahaan manufaktur non go public.
a. Jika nilai $Z>2,9 \quad=$ Zona Aman.
b. Jika nilai $1,23<\mathrm{Z}<2,9=$ Zona Abu-abu
c. Jika nilai $\mathrm{Z}<1,23=$ Zona Berbahaya 


\section{Metode Z-Score Altman ketiga (Modivikasi)}

Setelah melakukan penelitian dengan objek berbagai perusahaan manufaktur dan menghasilkan 2 rumus pendeteksi kebangkrutan. Altman melakukan penelitian lagi mengenai potensi kebangkrutan perusahaan-perusahaan selain perusahaan manufaktur, baik yang go public maupun yang tidak. Skor tersebut harus dibandingkan dengan standar penilaian berikut ini untuk menilai keberlangsungan hidup perusahaan:
a. Jika nilai $Z>2,60$
= Zona Aman.
b. Jika nilai $1,10<Z<2,60$
= Zona Abu-abu
c. Jika nilai $Z<1,10$
= Zona Berbahaya

Tiga penelitian yang dilakukan Altman dengan 3 (tiga) objek yang berbeda menghasilkan tiga rumus pendeteksi kebangkrutan yang berbeda. Tolak ukur dari ketiga rumus Z-Score yang digunakan untuk menilai keberlangsungan hidup berbagai kategori perusahaan, dapat diringkas sebagai berikut:

\section{Tabel 1}

Standar Penilaian dalam pendekatan Z-score Altman

\begin{tabular}{|c|c|c|c|}
\hline $\begin{array}{l}\text { Perusahaan } \\
\text { Manufaktur } \\
\text { Go Public }\end{array}$ & $\begin{array}{c}\text { Perusahaan } \\
\text { Manufaktur } \\
\text { Non Go Public }\end{array}$ & $\begin{array}{l}\text { Berbagai } \\
\text { Jenis } \\
\text { Perusahaan }\end{array}$ & Interpretasi \\
\hline$Z>2,99$ & $Z>2,90$ & $Z>2,60$ & $\begin{array}{l}\text { Zona Aman (Safe Zone), dimana perusahaan } \\
\text { dalam kondisi sehat sehingga kemungkinan } \\
\text { kebangkrutan sangat kecil terjadi. }\end{array}$ \\
\hline $\begin{array}{l}1,81<Z< \\
2,99\end{array}$ & $1,23<Z<2,90$ & $\begin{array}{l}1,10<Z< \\
2,60\end{array}$ & $\begin{array}{l}\text { Zona abu-abu, perusahaan dalam kondisi } \\
\text { rawan (grey zone). Pada kondisi ini } \\
\text { perusahaan mengalami masalah keuangan } \\
\text { yang harus ditangani dengan cara yang tepat. }\end{array}$ \\
\hline$Z<1,81$ & $Z<1,23$ & $\mathrm{Z}<1,10$ & $\begin{array}{l}\text { Zona berbahaya (distress zone), perusahaan } \\
\text { dalam kondisi bangkrut (mengalami kondisi } \\
\text { kesulitan keuangan dan risiko yang tinggi }\end{array}$ \\
\hline
\end{tabular}

\section{Metode X-Score Zmijewski}

Menurut Sari (2014) metode prediksi yang dihasilkan oleh Zmijewski merupakan riset selama 20 tahun yang telah diulang. Zmijewski menggunakan analisis rasio likuiditas, leverage, dan mengukur kinerja suatu perusahaan. Zmijewski melakukan prediksi dengan sampel 75 perusahaan bangkrut dan 73 perusahaan sehat selama tahun 1972 sampai tahun 1978, indikator F-Test terhadap rasio kelompok rate of return, liquidity, leverage turnover, fixed payment coverage, trens, firm size dan stock return volatility, menunjukkan perbedaan signifikan antara perusahaan yang sehat dan tidak sehat, dengan kriteria:

Jika skor yang didapatkan lebih dari 0 (nol), maka perusahaan diprediksi akan mengalami financial distress. Tetapi jika skor yang didapat kurang dari 0 (nol) maka perusahaan diprediksi tidak berpotensi mengalami masalah keuangan maupun kebangkrutan. 


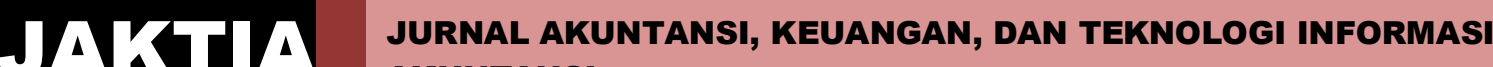

\section{KERANGKA TEORITIK}

Tabel 2

Kerangka Teoritik

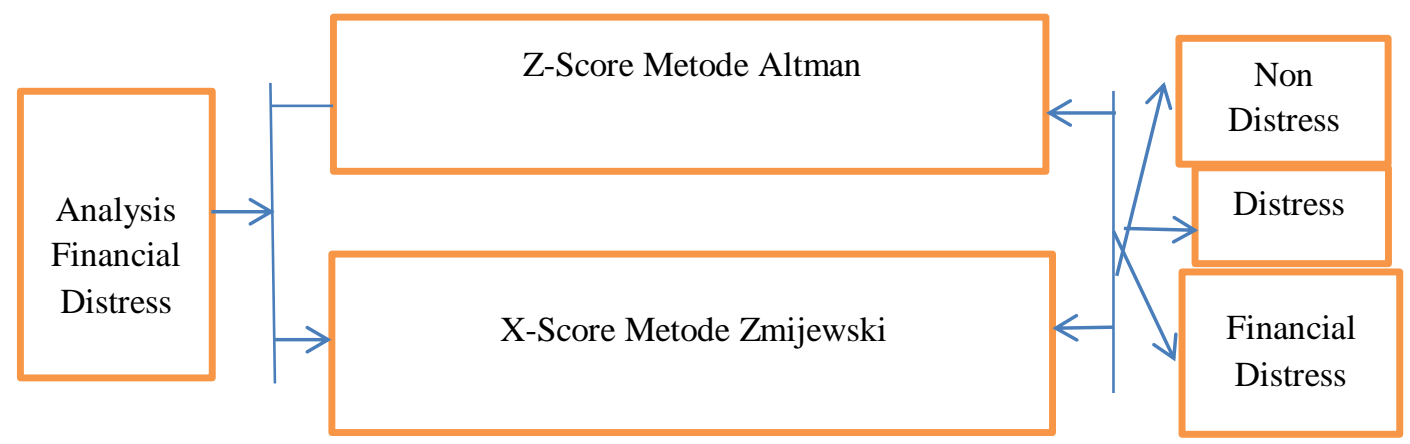

Metode X-Soce Altman merupakan gabungan dari lima unsur yang berbeda, dimana setiap unsur merupakan rasio keuangan yang berbeda. Hasil perhitungan rasio tersebut akan menghasilkan skor yang berbeda antara satu perusahaan dengan perusahaan lainnya. Skor tersebut harus dibandingkan dengan standar penilaian untuk menentukan nilai keberlangsungan hidup perusahaan.

Ketika:

- $\quad Z>2,99$ maka perusahaan dianggap berada pada zona aman.

- $1,81<\mathrm{Z}<2,99$ maka perusahaan dianggap berada pada zona abu-abu

- $\mathrm{Z}<1,81$ maka perusahaan dianggap berada pada zona berbahaya atau diprediksi akan mengalami kebangkrutan.

Sedangkan pada penggunaan metode X-Score Zmijewski, menggunakan metode yang mengkombinasikan beberapa rasio keuangan umum yang memberikan bobot yang berbeda satu dengan yang lainnya. Itu berarti, dengan menggunakan metode Zmijewski dapat diprediksi kemungkinan kebangkrutan suatu perusahaan.

Jika skor yang didapatkan lebih dari 0 (nol), maka perusahaan diprediksi akan mengalami financial distress. Tetapi jika skor yang didapat kurang dari 0 (nol) maka perusahaan diprediksi tidak berpotensi mengalami masalah keuangan maupun kebangkrutan.

\section{Metode Penelitian}

Penelitian ini merupakan model analisis deskriptif kuantitatif, yaitu dengan cara "mengumpulkan, mengidentifikasi, membatasi, merumuskan masalah yang biasanya dinyatakan dalam bentuk kalimat tanya. Berdasarkan rumusan masalah tersebut maka peneliti menggunakan beberapa teori dalam penilaian kuantitatif ini untuk menjawab rumusan masalah penelitian tersebut" (Sugiono 2016:31). Penelitian ini dilakukan dengan cara memperoleh data yang berbentuk angka yaitu data laporan keuangan tahunan pada Perusahaan manufaktur yang terdaftar di Bursa Efek Indonesia (BEI) Yang dapat diakses melalui sistus resminya yaitu www.idx.co.id yang sudah memenuhi kriteria untuk dijadikan sampel.

POPUlaSi DAN SAMPEL

Populasi adalah wilayah generalisasi yang terdiri atas objek atau subjek yang mempunyai kualitas dan karakteristik tertentu yang ditetapkan oleh peneliti untuk dipelajari dan kemudian 
ditarik kesimpulannya. Sedangkan sampel merupakan bagian dari jumlah dan karakteristik yang dimiliki oleh populasi tersebut (Sugiono 2016:81).

Pada penelitian kali ini, terdapat populasi sebanyak 426 perusahaan dengan jumlah sampel yang telah ditetapkan berdasarkan kriteria yaitu 46 perusahaan dengan total sampel penelitian sebanyak 138 perusahaan. Populasi dan sampel dalam penelitian ini adalah semua perusahaan manufaktur yang terdaftar di Bursa Efek Indonesia (BEI) dengan menggunakan metode purposive sampling. Dimana metode ini merupakan teknik penentuan sampel dengan pertimbangan tertentu. Kriteria sampel yang akan digunakan:

1. Perusahaan manufaktur yang tercatat di Bursa Efek Indonesia periode 2016-2018.

2. Perusahaan manufaktur yang mempunyai laporan keuangan dan laporan tahunan secara lengkap, serta dinyatakan dalam rupiah selama periode 2016-2018.

\section{Teknik Pengumpulan Data}

Teknik pengumpulan adalah data sekunder yaitu dengan cara mempelajari dan memahami buku yang mempunyai hubungan dengan metode Z-score Altman dan metode X-Score Zmijewski analisis prediksi kebangkrutan perusahaan dengan menggunakan laporan keuangan dan laporan tahunan seperti dari literatur, jurnal-jurnal, media massa dan hasil penelitian yang diperoleh dari berbagai sumber, baik dari perpustakaan dan sumber lain.

\section{TEKNIK ANALISIS DATA}

Teknik analisis data diarahkan untuk menjawab rumusan masalah atau menguji hipotesis yang telah dirumuskan dalam proposal (Sugiono 2016: 243).

Analisis data yang digunakan dalam penelitian ini adalah analisis data kuantitatif yaitu suatu teknik analisis data dengan menggunakan perhitungan angka-angka dari laporan keuangan, seperti neraca, laba rugi dan penjualan, yang kemudian digunakan sebagai dasar pengambilan keputusan. Teknik analisa yang digunakan dalam penilitian ini adalah dengan menghitung lima rasio keuangan Altman, dan tiga rasio keuangan Zmijewski, terhadap perusahaan yang terdapat dalam sampel penelitian ini.

\section{Metode model Altman}

$$
Z=1,2 X_{1}+1,4 X_{2}+3,3 X_{3}+0,6 X_{4}+1,0 X_{5}
$$

Dimana:

Working Capital to Total asset Ratio

$\left(\mathrm{X}_{1}\right)=\underline{\text { Modal Kerja }}$

Total Aset

Retained Earning to Total Asset Ratio

$\left(\mathrm{X}_{2}\right)=\underline{\text { Laba Ditahan }}$

Total Aset

Earning Power of Total Investment Ratio

$\left(\mathrm{X}_{3}\right)=\frac{\text { EBIT }}{\text { Total Aset }}$

Book Value of Equity to Total Liabitities Ratio

$\left(X_{4}\right)=\frac{\text { Nilai Saham }}{\text { Total Utang }}$

Total Utang 
Total Aseets Turnover Ratio

$\left(\mathrm{X}_{5}\right)=\frac{\text { Penjualan }}{\text { Total Aset }}$

Altman menyatakan bahwa jika perusahaan memiliki indeks kebangkrutan 2,99 atau di atasnya, maka perusahaan tidak termasuk yang dikategorikan akan mengalami kebangkrutan. Sedangkan perusahaan yang memiliki indeks kebangkrutan 1,81 atau dibawahnya, perusahaan tersebut termasuk kategori bangkrut.

Hasil perhitungan dengan menggunakan rumus Z-score tersebut akan menghasilkan skor yang berbeda antara suatu perusahaan dengan perusahaan lainnya. Skor tersebut harus dibandingkan dengan standar penilaian berikut ini untuk menilai keberlangsungan hidup perusahaan:
a. Jika nilai $Z>2,99$
= Zona Aman.
b. Jika nilai $1,81<\mathrm{Z}<2,99=$ Zona Abu-abu
c. Jika nilai $Z<1,81=$ Zona Berbahaya

Metode Model Zmijewski

$Z=-4,3-4,5 X_{1}+5,7 X_{2}+0,004 X_{3}$

Dimana:

Return to Total Assets Ratio

$\left(\mathrm{X}_{1}\right)=\underline{\text { Laba Setelah pajak }}$

Total Aset

Total Debt to Total Assets Ratio

$\left(\mathrm{X}_{2}\right)=\underline{\text { Total Utang }}$

Total Aset

Current Ratio

$\left(X_{3}\right)=\frac{\text { Aset Lancar }}{\text { Kewajiban Lancar }}$

\section{HASIL DAN PEMBAHASAN}

\section{Metode Z-Score Altman}

Hasil Prediksi Kebangkrutan Metode Z-score Altman

Berdasarkan perhitungan kumulatif 5 variabel indikator kebangkrutan pada pendekatan Z-score Altman, berikut merupakan hasil perhitungan nilai Z-score dari perusahaan manufaktur yang terdaftar di Bursa Efek Indonesia tahun 2016-2018 yang disajikan dalam bentuk tabel sebagai berikut: 
Tabel 3

Rata-Rata Z-Score Altman Pada Perusahaan Manufaktur Tahun 2016-2018

\begin{tabular}{|c|c|c|c|c|}
\hline NO & TAHUN & PERUSAHAAN & Z-SCORE & KLASIFIKASI \\
\hline \multirow{3}{*}{1} & 2016 & Astra Otopart Tbk & 3.120437505 & Zona Aman \\
\hline & 2017 & & 3.231957083 & Zona Aman \\
\hline & 2018 & & 2.131337972 & Zona Abu-abu \\
\hline \multirow{3}{*}{2} & 2016 & Trisula Textile Industries Tbk & 1.944448185 & Zona Abu-abu \\
\hline & 2017 & & 2.500100901 & Zona Abu-abu \\
\hline & 2018 & & 2.688088653 & Zona Abu-abu \\
\hline \multirow{3}{*}{3} & 2016 & Primarindo Asia Infrastructure & 1.536274849 & Zona Berbahaya \\
\hline & 2017 & & -0.925165678 & Zona Berbahaya \\
\hline & 2018 & & -0.785731536 & Zona Berbahaya \\
\hline \multirow{3}{*}{4} & 2016 & Indomobil Sukses Internasional & 0.816916837 & Zona Berbahaya \\
\hline & 2017 & & 0.731443631 & Zona Berbahaya \\
\hline & 2018 & & 0.545386681 & Zona Berbahaya \\
\hline \multirow{3}{*}{5} & 2016 & Indospring Tbk & 2.146611089 & Zona Abu-abu \\
\hline & 2017 & & 3.429790384 & Zona Abu-abu \\
\hline & 2018 & & 4.953322747 & Zona Abu-abu \\
\hline \multirow{3}{*}{6} & 2016 & Sunson Textile Manufacture Tbk & 4.58190931 & Zona Aman \\
\hline & 2017 & & 9.952501781 & Zona Aman \\
\hline & 2018 & & 12.81768459 & Zona Aman \\
\hline \multirow{3}{*}{7} & 2016 & KMI Wire \& Cable Tbk & 3.735781548 & Zona Aman \\
\hline & 2017 & & 4.82255125 & Zona Aman \\
\hline & 2018 & & 4.142750593 & Zona Aman \\
\hline \multirow{3}{*}{8} & 2016 & Selamat Sampurna Tbk & 8.49717926 & Zona Aman \\
\hline & 2017 & & 10.23225832 & Zona Aman \\
\hline & 2018 & & 10.11909926 & Zona Aman \\
\hline \multirow{3}{*}{9} & 2016 & Buana Artha Anugerah Tbk & 1.479893306 & Zona Berbahaya \\
\hline & 2017 & & 3.006439929 & Zona Aman \\
\hline & 2018 & & 2.667564085 & Zona Abu-abu \\
\hline \multirow{3}{*}{10} & 2016 & Trisula Internasional Tbk & 2.33464549 & Zona Abu-abu \\
\hline & 2017 & & 3.256496171 & Zona Aman \\
\hline & 2018 & & 2.589053704 & Zona Abu-abu \\
\hline \multirow{3}{*}{11} & 2016 & Nusantara Inti Corpora Tbk & 0.426073563 & Zona Berbahaya \\
\hline & 2017 & & 0.456899047 & Zona Berbahaya \\
\hline & 2018 & & 0.517921578 & Zona Berbahaya \\
\hline \multirow{3}{*}{12} & 2016 & Aneka Gas Industri Tbk & 3.961008114 & Zona Aman \\
\hline & 2017 & & 0.984976604 & Zona Berbahaya \\
\hline & 2018 & & 0.966269083 & Zona Berbahaya \\
\hline 13 & 2016 & Argha Karya Prima Industry Tbk & 1.40200221 & Zona Berbahaya \\
\hline
\end{tabular}




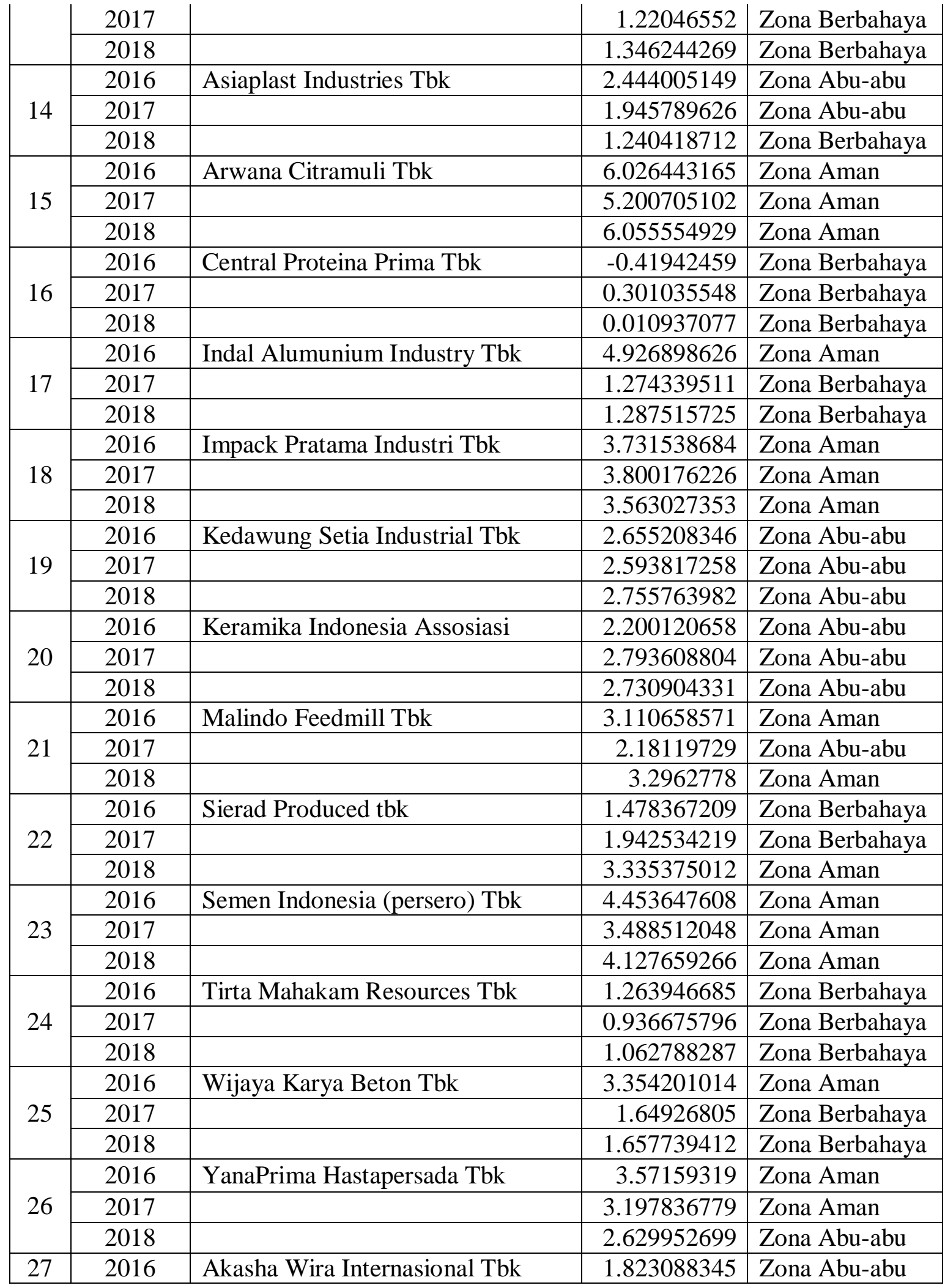




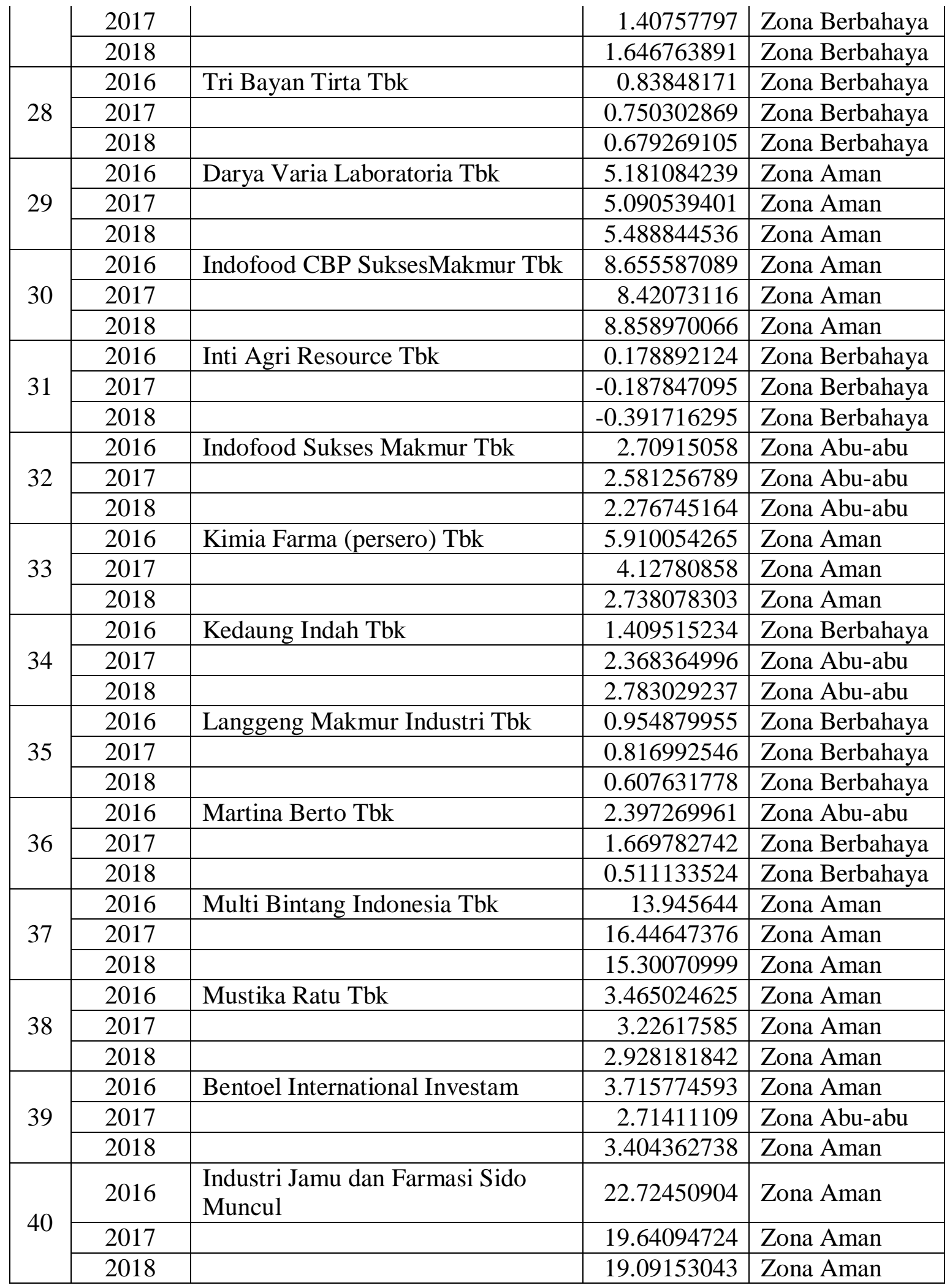




\begin{tabular}{|l|l|l|r|l|}
\multirow{4}{*}{41} & 2016 & Mandom Indonesia Tbk & 14.92733229 & Zona Aman \\
\cline { 2 - 5 } & 2017 & & 16.27781055 & Zona Aman \\
\cline { 2 - 5 } & 2018 & & 16.00854111 & Zona Aman \\
\hline \multirow{4}{*}{42} & 2016 & Tempo Scan Pasific Tbk & 5.784080623 & Zona Aman \\
\cline { 2 - 5 } & 2017 & & 4.914428669 & Zona Aman \\
\cline { 2 - 5 } & 2018 & & 4.38841642 & Zona Aman \\
\hline \multirow{4}{*}{43} & 2016 & Ultra Jaya Milk Industry & 3.381006093 & Zona Aman \\
\cline { 2 - 5 } & 2017 & & 3.112739648 & Zona Aman \\
\cline { 2 - 5 } & 2018 & & 2.994677695 & Zona Aman \\
\hline \multirow{4}{*}{44} & 2016 & Unilever Indonesia Tbk & 18.92863207 & Zona Aman \\
\cline { 2 - 5 } & 2017 & & 22.54952985 & Zona Aman \\
\cline { 2 - 5 } & 2018 & & 21.97381346 & Zona Aman \\
\hline \multirow{4}{*}{45} & 2016 & Wismilak Inti Makmur Tbk & 4.371503357 & Zona Aman \\
\cline { 2 - 6 } & 2017 & & 4.488534521 & Zona Aman \\
\cline { 2 - 6 } & 2018 & & 1.282410906 & Zona Aman \\
\hline \multirow{3}{*}{46} & 2016 & Budi Strach \& Sweetener Tbk & 1.577453138 & Zona Berbahaya \\
\cline { 2 - 6 } & 2017 & & 1.65578764 & Zona Berbahaya \\
\cline { 2 - 6 } & 2018 & & 1.479876881 & Zona Berbahaya \\
\hline
\end{tabular}

Sumber: Data Sekunder Diolah, 2020

Dari hasil perhitungan dan analisis berdasarkan perhitungan kumulatif 5 variabel indikator kebangkrutan pada pendekatan Z-score Altman, dapat tergambar bahwa tingkat kebangrutan perusahaan manufaktur yang terdaftar di Bursa Efek Indonesia tahun 2016-2018 terlihat sebagai beriku; pada tahun 2016 menunjukkan bahwa terdapat 24 perusahaan dalam zona aman, 9 perusahaan dalam zona abu-abu dan 13 perusahaan dalam zona berbahaya. pada tahun 2017, terdapat 21 perusahaan dalam zona aman, 9 perusahaan dalam zona abu-abu dan 16 perusahaan dalam zona berbahaya. Sedangkan pada tahun 2018 terdapat 20 perusahaan dalam zona aman, 10 perusahaan dalam zona abu-abu dan 16 perusahaan dalam zona berbahaya.

\section{Metode X-score Zmijewski}

\section{Hasil Prediksi Kebangkrutan Metode X-score Zmijewski}

Berdasarkan perhitungan kumulatif 3 variabel indikator kebangkrutan pada pendekatan X-score Zmijewski, berikut merupakan hasil perhitungan nilai X-score dari perusahaan manufaktur yang terdaftar di Bursa Efek Indonesia tahun 2016-2018 yang disajikan dalam bentuk tabel sebagai berikut:

Tabel 4

Rata-Rata X-Score Zmijewski Pada Perusahaan Manufaktur Tahun 2016-2018

\begin{tabular}{|c|c|l|c|c|}
\hline \multirow{2}{*}{ NO } & \multirow{2}{*}{ TAHUN } & PERUSAHAAN & X-SCORE & INTERPRETASI \\
& & & & \\
\hline \multirow{2}{*}{1} & 2016 & Astra Otopart Tbk & -2.852986371 & Zona kebangkrutan \\
\cline { 2 - 5 } & 2017 & & -2.914381863 & Zona kebangkrutan \\
\cline { 2 - 5 } & 2018 & & -0.44635245 & Zona kebangkrutan \\
\hline
\end{tabular}




\begin{tabular}{|c|c|c|c|c|}
\hline \multirow{3}{*}{2} & 2016 & Trisula Textile Industries Tbk & -0.076907638 & Zona kebangkrutan \\
\hline & 2017 & & -1.68387437 & Zona kebangkrutan \\
\hline & 2018 & & -1.683739069 & Zona kebangkrutan \\
\hline \multirow{3}{*}{3} & 2016 & Primarindo Asia Infrastructure & 6.570354822 & zona aman \\
\hline & 2017 & & 6.008532019 & zona aman \\
\hline & 2018 & & 5.989344119 & zona aman \\
\hline \multirow{3}{*}{4} & 2016 & Indomobil Sukses Internasional & -0.033242664 & Zona kebangkrutan \\
\hline & 2017 & & -0.271749431 & Zona kebangkrutan \\
\hline & 2018 & & -0.044576662 & Zona kebangkrutan \\
\hline \multirow{3}{*}{5} & 2016 & Indospring Tbk & -3.43633218 & Zona kebangkrutan \\
\hline & 2017 & & -3.811057827 & Zona kebangkrutan \\
\hline & 2018 & & -3.818251591 & Zona kebangkrutan \\
\hline \multirow{3}{*}{6} & 2016 & Sunson Textile Manufacture Tbk & -0.569313549 & Zona kebangkrutan \\
\hline & 2017 & & -0.416628475 & Zona kebangkrutan \\
\hline & 2018 & & -0.782456246 & Zona kebangkrutan \\
\hline \multirow{3}{*}{7} & 2016 & KMI Wire \& Cable Tbk & -3.414871512 & Zona kebangkrutan \\
\hline & 2017 & & -2.50742305 & Zona kebangkrutan \\
\hline & 2018 & & -2.484663138 & Zona kebangkrutan \\
\hline \multirow{3}{*}{8} & 2016 & Selamat Sampurna Tbk & -3.58449974 & Zona kebangkrutan \\
\hline & 2017 & & -3.873154864 & Zona kebangkrutan \\
\hline & 2018 & & -3.977286253 & Zona kebangkrutan \\
\hline \multirow{3}{*}{9} & 2016 & Buana Artha Anugerah Tbk & -2.641958987 & Zona kebangkrutan \\
\hline & 2017 & & -3.139543586 & Zona kebangkrutan \\
\hline & 2018 & & -3.138442101 & Zona kebangkrutan \\
\hline \multirow{3}{*}{10} & 2016 & Trisula Internasional Tbk & -1.852195301 & Zona kebangkrutan \\
\hline & 2017 & & -2.435485206 & Zona kebangkrutan \\
\hline & 2018 & & -1.940997864 & Zona kebangkrutan \\
\hline \multirow{3}{*}{11} & 2016 & Nusantara Inti Corpora Tbk & -1.819289415 & Zona kebangkrutan \\
\hline & 2017 & & -1.886923513 & Zona kebangkrutan \\
\hline & 2018 & & -1.942275117 & Zona kebangkrutan \\
\hline \multirow{3}{*}{12} & 2016 & Aneka Gas Industri Tbk & -1.42373938 & Zona kebangkrutan \\
\hline & 2017 & & -1.71744514 & Zona kebangkrutan \\
\hline & 2018 & & -1.371552732 & Zona kebangkrutan \\
\hline \multirow{3}{*}{13} & 2016 & Argha Karya Prima Industry Tbk & -1.126151725 & Zona kebangkrutan \\
\hline & 2017 & & -0.956829322 & Zona kebangkrutan \\
\hline & 2018 & & -0.980383704 & Zona kebangkrutan \\
\hline \multirow{3}{*}{14} & 2016 & Asiaplast Industries Tbk & -2.849445897 & Zona kebangkrutan \\
\hline & 2017 & & -1.98065251 & Zona kebangkrutan \\
\hline & 2018 & & -0.69886011 & Zona kebangkrutan \\
\hline \multirow{3}{*}{15} & 2016 & Arwana Citramuli Tbk & -2.362897083 & Zona kebangkrutan \\
\hline & 2017 & & -2.600998384 & Zona kebangkrutan \\
\hline & 2018 & & -2.805350551 & Zona kebangkrutan \\
\hline
\end{tabular}




\begin{tabular}{|c|c|c|c|c|}
\hline \multirow{3}{*}{16} & 2016 & Central Proteina Prima Tbk & 2.497082128 & zona aman \\
\hline & 2017 & & 4.542114116 & zona aman \\
\hline & 2018 & & -0.36187026 & Zona kebangkrutan \\
\hline \multirow{3}{*}{17} & 2016 & Indal Alumunium Industry Tbk & 0.18621026 & zona aman \\
\hline & 2017 & & -0.041876781 & Zona kebangkrutan \\
\hline & 2018 & & 0.037459308 & zona aman \\
\hline \multirow{3}{*}{18} & 2016 & Impack Pratama Industri Tbk & 2.769929129 & zona aman \\
\hline & 2017 & & 2.038004711 & zona aman \\
\hline & 2018 & & 1.621536236 & zona aman \\
\hline \multirow{3}{*}{19} & 2016 & Kedawung Setia Industrial Tbk & -2.385986389 & Zona kebangkrutan \\
\hline & 2017 & & -0.912456217 & Zona kebangkrutan \\
\hline & 2018 & & -1.117860319 & Zona kebangkrutan \\
\hline \multirow{3}{*}{20} & 2016 & Keramika Indonesia Assosiasi & -2.635217477 & Zona kebangkrutan \\
\hline & 2017 & & -2.971197293 & Zona kebangkrutan \\
\hline & 2018 & & -2.910121078 & Zona kebangkrutan \\
\hline \multirow{3}{*}{21} & 2016 & Malindo Feedmill Tbk & -1.398008909 & Zona kebangkrutan \\
\hline & 2017 & & -0.971617532 & Zona kebangkrutan \\
\hline & 2018 & & -1.506725095 & Zona kebangkrutan \\
\hline \multirow{3}{*}{22} & 2016 & Sierad Produced tbk & -1.154736615 & Zona kebangkrutan \\
\hline & 2017 & & 0.103600842 & zona aman \\
\hline & 2018 & & -0.838629018 & Zona kebangkrutan \\
\hline \multirow{3}{*}{23} & 2016 & Semen Indonesia (persero) Tbk & -2.996794614 & Zona kebangkrutan \\
\hline & 2017 & & -2.271351976 & Zona kebangkrutan \\
\hline & 2018 & & -2.511245224 & Zona kebangkrutan \\
\hline \multirow{3}{*}{24} & 2016 & Tirta Mahakam Resources Tbk & 0.358844532 & zona aman \\
\hline & 2017 & & 0.57800106 & zona aman \\
\hline & 2018 & & 1.042046215 & zona aman \\
\hline \multirow{3}{*}{25} & 2016 & Wijaya Karya Beton Tbk & -1.912250324 & Zona kebangkrutan \\
\hline & 2017 & & -1.028717733 & Zona kebangkrutan \\
\hline & 2018 & & -0.855175302 & Zona kebangkrutan \\
\hline \multirow{3}{*}{26} & 2016 & YanaPrima Hastapersada Tbk & -1.308668129 & Zona kebangkrutan \\
\hline & 2017 & & -0.767901218 & Zona kebangkrutan \\
\hline & 2018 & & -0.508884664 & Zona kebangkrutan \\
\hline \multirow{3}{*}{27} & 2016 & Akasha Wira Internasional Tbk & -1.78287865 & Zona kebangkrutan \\
\hline & 2017 & & -1.669630019 & Zona kebangkrutan \\
\hline & 2018 & & -1.981841375 & Zona kebangkrutan \\
\hline \multirow{3}{*}{28} & 2016 & Tri Bayan Tirta Tbk & -0.848282338 & Zona kebangkrutan \\
\hline & 2017 & & -0.495540977 & Zona kebangkrutan \\
\hline & 2018 & & -0.451258279 & Zona kebangkrutan \\
\hline \multirow{3}{*}{29} & 2016 & Darya Varia Laboratoria Tbk & -3.053864149 & Zona kebangkrutan \\
\hline & 2017 & & -2.912034776 & Zona kebangkrutan \\
\hline & 2018 & & -3.190491963 & Zona kebangkrutan \\
\hline
\end{tabular}




\begin{tabular}{|c|c|c|c|c|}
\hline \multirow{3}{*}{30} & 2016 & $\begin{array}{l}\text { Indofood CBP SuksesMakmur } \\
\text { Tbk }\end{array}$ & -2.673488633 & Zona kebangkrutan \\
\hline & 2017 & & -2.75837268 & Zona kebangkrutan \\
\hline & 2018 & & -2.96832944 & Zona kebangkrutan \\
\hline \multirow{3}{*}{31} & 2016 & Inti Agri Resource Tbk & -2.634406453 & Zona kebangkrutan \\
\hline & 2017 & & -3.655625165 & Zona kebangkrutan \\
\hline & 2018 & & -3.614558429 & Zona kebangkrutan \\
\hline \multirow{3}{*}{32} & 2016 & Indofood Sukses Makmur Tbk & -1.930368142 & Zona kebangkrutan \\
\hline & 2017 & & -1.89295638 & Zona kebangkrutan \\
\hline & 2018 & & -1.774324882 & Zona kebangkrutan \\
\hline \multirow{3}{*}{33} & 2016 & Kimia Farma (persero) Tbk & -1.665018704 & Zona kebangkrutan \\
\hline & 2017 & & -1.24402356 & Zona kebangkrutan \\
\hline & 2018 & & -0.807728062 & Zona kebangkrutan \\
\hline \multirow{3}{*}{34} & 2016 & Kedaung Indah Tbk & -2.219198203 & Zona kebangkrutan \\
\hline & 2017 & & -2.300584908 & Zona kebangkrutan \\
\hline & 2018 & & -2.051320159 & Zona kebangkrutan \\
\hline \multirow{3}{*}{35} & 2016 & Langgeng Makmur Industri Tbk & -1.503504554 & Zona kebangkrutan \\
\hline & 2017 & & -0.995584084 & Zona kebangkrutan \\
\hline & 2018 & & -0.723648911 & Zona kebangkrutan \\
\hline \multirow{3}{*}{36} & 2016 & Martina Berto Tbk & -2.620047323 & Zona kebangkrutan \\
\hline & 2017 & & -1.463038231 & Zona kebangkrutan \\
\hline & 2018 & & -0.444128351 & Zona kebangkrutan \\
\hline \multirow{3}{*}{37} & 2016 & Multi Bintang Indonesia Tbk & -2.595996775 & Zona kebangkrutan \\
\hline & 2017 & & -3.385098081 & Zona kebangkrutan \\
\hline & 2018 & & -2.807505192 & Zona kebangkrutan \\
\hline \multirow{3}{*}{38} & 2016 & Mustika Ratu Tbk & -2.887797693 & Zona kebangkrutan \\
\hline & 2017 & & -2.776977128 & Zona kebangkrutan \\
\hline & 2018 & & -2.664103889 & Zona kebangkrutan \\
\hline \multirow{3}{*}{39} & 2016 & Bentoel International Investam & -1.888408112 & Zona kebangkrutan \\
\hline & 2017 & & -2.050603723 & Zona kebangkrutan \\
\hline & 2018 & & -1.462919765 & Zona kebangkrutan \\
\hline \multirow{3}{*}{40} & 2016 & $\begin{array}{l}\text { Industri Jamu dan Farmasi Sido } \\
\text { Muncul }\end{array}$ & -4.552087954 & Zona kebangkrutan \\
\hline & 2017 & & -4.555876086 & Zona kebangkrutan \\
\hline & 2018 & & -4.435321107 & Zona kebangkrutan \\
\hline \multirow{3}{*}{41} & 2016 & Mandom Indonesia Tbk & -3.563950577 & Zona kebangkrutan \\
\hline & 2017 & & -3.406535526 & Zona kebangkrutan \\
\hline & 2018 & & -3.504593427 & Zona kebangkrutan \\
\hline \multirow{3}{*}{42} & 2016 & Tempo Scan Pasific Tbk & -2.97393757 & Zona kebangkrutan \\
\hline & 2017 & & -2.823390543 & Zona kebangkrutan \\
\hline & 2018 & & -2.833777843 & Zona kebangkrutan \\
\hline
\end{tabular}




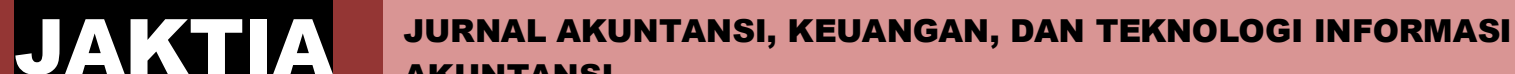 AKUNTANSI}

\begin{tabular}{|c|c|l|c|c|}
\multirow{4}{*}{43} & 2016 & Ultra Jaya Milk Industry & -4.024647782 & Zona kebangkrutan \\
\cline { 2 - 5 } & 2017 & & -3.824743608 & Zona kebangkrutan \\
\cline { 2 - 5 } & 2018 & & -4.049503582 & Zona kebangkrutan \\
\hline \multirow{3}{*}{44} & 2016 & Unilever Indonesia Tbk & -1.916031097 & Zona kebangkrutan \\
\cline { 2 - 5 } & 2017 & & -1.824304624 & Zona kebangkrutan \\
\cline { 2 - 5 } & 2018 & & -2.909210551 & Zona kebangkrutan \\
\hline \multirow{3}{*}{45} & 2016 & Wismilak Inti Makmur Tbk & -3.113152652 & Zona kebangkrutan \\
\cline { 2 - 5 } & 2017 & & -3.276065938 & Zona kebangkrutan \\
\cline { 2 - 5 } & 2018 & & -3.323150653 & Zona kebangkrutan \\
\hline \multirow{3}{*}{46} & 2016 & Budi Strach \& Sweetener Tbk & -0.920276905 & Zona kebangkrutan \\
\cline { 2 - 5 } & 2017 & & -0.982517168 & Zona kebangkrutan \\
\cline { 2 - 6 } & 2018 & & -0.723331921 & Zona kebangkrutan \\
\hline
\end{tabular}

Sumber: Data Sekunder Diolah, 2020

Dari hasil perhitungan dan analisis tingkat kebangkrutan berdasarkan pendekatan X-score Zmijewski, maka dapat tergambar bahwa tingkat kebangkrutan untuk tahun tahun 2016 dan 2017 menunjukkan bahwa hanya terdapat 5 perusahaan yang berada pada zona aman dan 41 perusahaan dalam zona berbahaya. Sedangkan pada tahun 2018 terdapat 4 perusahaan dalam zona aman dan 42 perusahaan lainnya dalam zona berbahaya.

\section{KESIMPULAN DAN SARAN}

Berdasarkan hasil penelitian yang telah dilakukan sebagaimana telah dibahas sebelumnya, maka dapat diambil kesimpulan sebagai berikut:

\section{Kesimpulan}

Penelitian ini disimpulkan bahwa dari perhitungan kedua metode tersebut, Hasil perhitungan nilai Z-score Altman, pada tahun 2016 menunjukkan bahwa terdapat 24 perusahaan dalam zona aman, 9 perusahaan dalam zona abu-abu dan 13 perusahaan dalam zona berbahaya. pada tahun 2017, terdapat 21 perusahaan dalam zona aman, 9 perusahaan dalam zona abu-abu dan 16 perusahaan dalam zona berbahaya. Sedangkan pada tahun 2018 terdapat 20 perusahaan dalam zona aman, 10 perusahaan dalam zona abu-abu dan 16 perusahaan dalam zona berbahaya. Hasil perhitungan nilai Xscore Zmijewski, pada tahun 2016 dan 2017 menunjukkan bahwa hanya terdapat 5 perusahaan yang berada pada zona aman dan 41 perusahaan dalam zona berbahaya. Sedangkan pada tahun 2018 terdapat 4 perusahaan dalam zona aman dan 42 perusahaan lainnya dalam zona berbahaya.

\section{Saran}

Bagi peneliti selanjutnya, penelitian ini diharapkan mampu menjadi referensi dan bahan acuan dalam melakukan peneltian. Serta diharapkan penelitian selanjutnya mampu menggunakan model prediksi kebangkrutan lainnya sebagai pembanding dalam analisi prediksi kebangkrutan perusahaan. 


\section{DAFTAR PUSTAKA}

Alif Fikri Alim, (2017). Analisis Prediksi Kebangkrutan Dengan Model Altman Z-score Pada Perusahaan Makanan Dan Minuman Yang Terdaftar Di Bursa Efek Indonesia. Yogyakarta: Universitas Islam Indonesia.

Brigham, Eugene F dan Joel F. Houston, (2014). Dasar-Dasar Manajemen Keungan Edisi 11- Buku 1. Jakarta: Salemba Empat.

Chicha Lestari, dkk, (2018). "Prediksi Kebangkrutan Berdasarkan Metode Altaman Z-Score (Studi Kasus Pada Perusahaan Makanan dan Minuman Yang Terdaftar Pada BEI 2011-2016)". Jurnal Manajemen, Juni 2018 hal.6-13 Vol 4 No.1. ISSN: 2339-1510

Dwi Martani, dkk, (2017). Akuntansi Keuangan Menengah Berbasis PSAK. Jakarta: Salemba Empat.

Fahmi, Irham, (2011). Analisis Laporan Keuangan. Lampulo: ALFABETA.

Indri Amaliah, (2016). Analisis Rasio Keuangan Dengan Model Zmijewski (X-score) Dalam Memprediksi Kebangkrutan Pada Perbankan Syariah Di Indonesia Tahun 2011-2015. Jakarta: Universitas Syarif Hidayatullah Jakarta.

Lia Anggraini, (2017). Prediksi zpotensi Kebangkrutan Perusahaan Manufaktur Yang Terdaftar Di Jakarta Islamic Index Menggunakan Metode Altman Z-score Periode 2011-2015. Bengkulu: Universitas Islam Negeri Bengkulu.

Mamduh M. Hanafi dan Abdul Halim, (2003). Analisis Laporan Keuangan Edisi Revisi. Yogyakarta: AMP-YKPN.

Munawir, S, (2012). Analisis Informasi Keuangan. Yogyakarta: Liberty.

Nindya Ayu Damayanti, dkk, (2019). "Analisis Perbandingan Model Prediksi Kebangkrutan Altman Score dan Zmijewski Di BEI Tahun 2011-2015”. E-jurnal Ekonomi Bisnis dan Akuntansi, Vol. VI (1):171-174. ISSN: 2355-4665.

Pricilia Pangkey Claudia, (2018). "Analisis Prediksi Kebangkrutan Dengan Menggunakan Metode Altman dan Metode Zmijewski Pada Perusahaan Bangkrut Yang Pernah Go Public Di Bursa Efek Indonesia”. Jurnal EMBA, Vol.6. No.4. ISSN: 2303-1174.

Rudianto, (2013). Akuntansi Manajemen Informasi Untuk Pengambilan Keputusan Strategis. Jakarta: Erlangga.

Sugiyono, (2016). Metode Penelitian Kuantitatif, Kualitatif, dan R\&D. Bandung: ALFABETA. 